\title{
Anticancer Effects of Oleocanthal and Pinus Pinaster on Breast Cancer Cell in Culture ${ }^{+}$
}

\author{
Mahmud Özkut 1,* , Gülşah Albayrak 1, Pınar Kılıçaslan Sönmez 1, Büşra Şen 1, Pelin Toros 1, \\ Şamil Öztürk ${ }^{2}$, Fatih Çöllü ${ }^{3}$, Sevinç İnan ${ }^{4}$ and Mehmet İbrahim Tuğlu ${ }^{1}$ \\ 1 Department of Histology and Embryology, Faculty of Medicine, Celal Bayar University, Manisa 45140, \\ Turkey; gulsahalbayrak@outlook.com (G.A.); klcsln.pnr@gmail.com (P.K.S.); torospelin@gmail.com (P.T.) \\ 2 Medical Services and Techniques, Çanakkale Vocational School of Health Services, Çanakkale Onsekiz \\ Mart University, Çanakkale 17100, Turkey; samilozturk16@hotmail.com \\ 3 Department of Biology, Faculty of Science, Celal Bayar University, Manisa 45140, Turkey; \\ fatih.collu@gmail.com \\ 4 Department of Histology and Embryology, Faculty of Medicine, İzmir University of Economics, \\ İzmir 35330, Turkey; sevincinan@yahoo.com \\ * Correspondence: mahmudozkut@yahoo.com.tr; Tel.: +90-544-729-3113 \\ + Presented at the 2nd International Conference on Natural Products for Cancer Prevention and Therapy, \\ Kayseri, Turkey, 8-11 November 2017.
}

Published: 17 November 2017

\begin{abstract}
Phytotherapy has been used for many years due to anticancer and anti-proliferative effects. In this study our purpose was to show the anti-proliferative and apoptotic effects of oleocanthal and pinus pinaster on MCF-7, MDA-MB-231, 67NR and 4T1 breast cancer cell lines. Biological effects of these plants were researched via morphology, MTT assay for cytotoxicity (IC50), immunocytochemical procedure for oxidative stress (eNOS), angiogenesis (VEGF) and TUNEL method for apoptosis. Statistical analysis was performed with the H-score. Oleocanthal and Pinus pinaster extracts showed significant dose and time-dependent inhibition of growth of breast cancer cells. A significant increase in iNOS staining was observed while a decrease in VEGF staining was observed after extract application at IC50 dose. The results showed a significant increase in apoptosis in extract-treated breast cancer cell lines. We showed that the toxic effect of Oleocanthal and Pinus pinaster extracts created by oxidative stress mechanisms. The increase of oxidative stress in breast cancer cells caused the inhibition of cell proliferation and apoptosis. Our results indicated that these plants suggest potential agents in breast cancer treatment. Future studies will focus on the identification of the molecules responsible for anti-cancer activity of these substances in order to improve the quality of life of the patients.
\end{abstract}

Keywords: oxidative stress; breast cancer; apoptosis

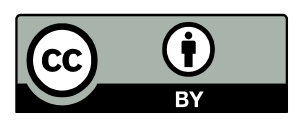

(C) 2017 by the authors. Licensee MDPI, Basel, Switzerland. This article is an open access article distributed under the terms and conditions of the Creative Commons Attribution (CC BY) license (http://creativecommons.org/licenses/by/4.0/). 